\begin{tabular}{|c|c|}
\hline Title & Soil carbon dioxide emissions from a rubber plantation on tropical peat \\
\hline Author(s) & Wakhid, Nur; Hirano, Takashi; Okimoto, Y osuke; Nurzakiah, Siti; Nursy amsi, Dedi \\
\hline Citation & $\begin{array}{l}\text { Science of the total environment, 581-582, 857-865 } \\
\text { https://doi.org/10.1016/.scitotenv.2017.01.035 }\end{array}$ \\
\hline Issue Date & 2017-03-01 \\
\hline DOC URL & http:/hdl.handle.net/2115/72327 \\
\hline Rights & $\begin{array}{l}\text { (2) 2017. This manuscript version is made available under the CC-BY-NC-ND } 4.0 \text { license } \\
\text { http://creativecommons.org/icenses/by-nc-nd/4.0/ }\end{array}$ \\
\hline Rights(URL) & http://creativecommons.org/icenses/by-nc-nd/4.0/ \\
\hline Type & article (author version) \\
\hline File Information & RevisedMS_Jabiren2.pdf \\
\hline
\end{tabular}

Instructions for use 


\title{
Soil carbon dioxide emissions from a rubber plantation on tropical peat
}

\author{
Nur Wakhid ${ }^{\mathrm{a}, \mathrm{c}}$, Takashi Hirano ${ }^{\mathrm{b}}$, Yosuke Okimoto $^{\mathrm{b}}$, Siti Nurzakiah ${ }^{\mathrm{c}}$ and \\ Dedi Nursyamsic

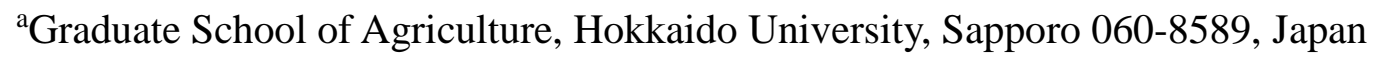 \\ ${ }^{\mathrm{b}}$ Research Faculty of Agriculture, Hokkaido University, Sapporo 060-8589, Japan \\ 'Indonesian Agency for Agricultural Research and Development (IAARD), Jakarta \\ 12540, Indonesia
}

\begin{abstract}
Land-use change in tropical peatland potentially results in a large amount of carbon dioxide $\left(\mathrm{CO}_{2}\right)$ emissions owing to drainage, which lowers groundwater level (GWL) and consequently enhances oxidative peat decomposition. However, field information on carbon balance is lacking for rubber plantations, which are expanding into Indonesia's peatlands. To assess soil $\mathrm{CO}_{2}$ emissions from an eight-year-old rubber plantation established on peat after compaction, soil $\mathrm{CO}_{2}$ efflux was measured monthly using a closed chamber system from December 2014 to December 2015, in which a strong El Niño event occurred, and consequently GWL lowered deeply. Total soil respiration (SR) and oxidative peat decomposition (PD) were separately quantified by trenching. In addition, peat surface elevation was measured to determine annual subsidence along with GWL. With GWL, SR showed a negative logarithmic relationship $(p<0.01)$, whereas PD showed a strong negative linearity $(p<0.001)$. Using the significant relationships, annual SR and PD were calculated from hourly GWL data to be $3293 \pm 1039$ and $1408 \pm 214 \mathrm{~g}$ $\mathrm{C} \mathrm{m}^{-2} \mathrm{yr}^{-1}$ (mean \pm 1 standard deviation), respectively. PD accounted for $43 \%$ of SR on an annual basis. SR showed no significant difference between near and far positions from rubber trees $(p>0.05)$. Peat surface elevation varied seasonally in almost parallel with GWL. After correcting for GWL difference, annual total subsidence was determined at $5.64 \pm 3.20$ and $5.96 \pm 0.43 \mathrm{~cm} \mathrm{yr}^{-1}$ outside and inside the trenching, respectively. Annual subsidence only through peat oxidation that was calculated from the annual PD, peat bulk

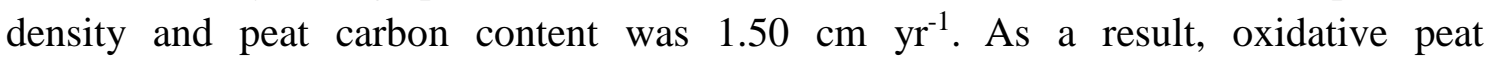
decomposition accounted for $25 \%$ of total subsidence $\left(5.96 \mathrm{~cm} \mathrm{yr}^{-1}\right.$ ) on average on an annual basis. The contribution of peat oxidation was lower than those of previous studies probably because of compaction through land preparation.
\end{abstract}

Keywords: Chamber method, groundwater level, oxidative peat decomposition, soil respiration, subsidence, trenching

\section{Introduction}


Peat soil represents an accumulation of organic matter over millennia, storing huge carbon as a thick layer. Despite covering only $11 \%$ of global peatland areas, tropical peatlands contain about $88.6 \mathrm{Gt}$ (15-19\% of the global peat carbon (C) pool), of which $77 \%$ were distributed in Southeast Asia (Page et al., 2011a). Indonesia has the largest area of tropical peatlands, which covers $2.48 \times 10^{7}$ ha and stores $68.5 \mathrm{Gt}$ of carbon mainly in Sumatra, Kalimantan and Papua Islands; $11.3 \mathrm{Gt}$ of carbon is stored as peat even only in Kalimantan (Page et al., 2011a; Ritung et al. 2011; Wahyunto et al. 2014). Peatlands in Central Kalimantan are one of prominent ecosystem carbon pools, which have accumulated throughout the Late Pleistocene and Holocene (Page et al., 2004). However, high demand for plantations has increased land clearing in Indonesia's peatlands during the last decades (Miettinen et al., 2012). In Central Kalimantan, peatlands have been converted to plantations since the failure of the large-scale land development (Mega Rice Project: MRP), through which peatlands of about more than half a million hectares were deforested, drained and burnt in 1995-1997 (Hooijer et al., 2014).

Land-use change in peatland is usually related to large carbon dioxide $\left(\mathrm{CO}_{2}\right)$ emissions due chiefly to drainage, which lowers groundwater level (GWL) and disturbs the peat soil condition (Furukawa et al., 2005; Couwenberg et al., 2009). Moreover, landuse change potentially changes peatland from an important carbon sink into a huge source of $\mathrm{CO}_{2}$ to the atmosphere and increases fire risks (Page et al. 2002; Page et al. 2011b, Agus et al., 2013; Schrier-Uijl et al., 2013). It is reported that annual carbon loss due to peat drainage and fires is on average 28 times larger than the pre-disturbance rate (Dommain et al., 2014). El Niño events bring about drought in most part of Indonesia, including peatland areas. In El Niño years, the dry season is prolonged, and consequently GWL lowers more (Hamada et al, 2002; Hirano et al., 2015). As a result, large-scale peat/forest fires frequently occur, and oxidative peat decomposition potentially accelerates.

$\mathrm{CO}_{2}$ emissions from peat soil have been typically assessed using two methods: the subsidence and chamber methods. The subsidence method measures the relative elevation of peat surface along with carbon content and bulk density of peat. On the other hand, the chamber method directly measures $\mathrm{CO}_{2}$ emission rates (efflux) from peat soil surface. The thickness of the peat layer reduces because of compaction, shrinkage, consolidation and oxidative peat decomposition which releases $\mathrm{CO}_{2}$ to the atmosphere. The subsidence method has an advantage as backwards interpretation of soil carbon loss. The principal question of the method is how to determine the resultant extent of peat oxidation (Hooijer et al. 2010). Although many researchers have attempted to determine the contribution of peat decomposition to total subsidence, it's still unclear. The role of peat oxidation in subsidence of the drained peat layers has not been sufficiently quantified yet (Couwenberg et al., 2009). As for the chamber method, there are several studies in farmland or plantations on tropical peat (Melling et al., 2005; Ali et al., 2006; Hirano et al., 2009; Jauhiainen et al., 2012; Marwanto and Agus, 2014; Husnain et al., 2014; Jauhiainen 2014). However, there are still a small number of studies that measured 
oxidative peat decomposition directly in the field (Comeau et al., 2016; Dariah et al., 2014; Husnain et al., 2014; Jauhiainen et al., 2012; Hirano et al., 2014; Melling et al., 2013). The direct measurement of soil $\mathrm{CO}_{2}$ emission, excluding root respiration, is critical to quantify $\mathrm{CO}_{2}$ emissions arising solely from peat decomposition. Moreover, to reduce uncertainties in the assessment of peat $\mathrm{CO}_{2}$ emissions, it is indispensable to understand the variability of peat decomposition with environmental factors.

Indonesia is the world's second largest natural rubber exporter after Thailand, with the largest area of rubber plantations in the world (Global Business Guide Indonesia, 2015). Rubber plantations with about 3.5 million ha in area are the third largest plantation in Indonesia after oil palm and coconut (Indonesia Directorate General of Estate, 2013). On peat, although the area of rubber plantation is still limited in comparison with those of oil palm and acacia plantations, rubber plantation has been expanding year by year. Thus, the impact of the land use conversion into rubber plantations on peat $\mathrm{CO}_{2}$ emissions should be assessed using field data. To our knowledge, there is only a few study to measure peat $\mathrm{CO}_{2}$ efflux in the rubber plantation (Husnain et al., 2014; Nurzakiah et al., 2014). The measurement of peat decomposition is important to make a meaningful comparison of the vulnerability of peat carbon among different sites and diverse vegetation covers (Melling and Henson, 2011). Therefore, we measured total soil $\mathrm{CO}_{2}$ efflux (total soil respiration: $\mathrm{SR}$ ) and $\mathrm{CO}_{2}$ efflux through peat decomposition (PD) by the trenching approach (Epron, 2009) using the chamber method along with peat subsidence in a rubber plantation on tropical peat throughout a year. Our objectives are 1) to investigate the seasonal variations of SR and PD in relation to GWL, 2) quantify annual SR and PD separately and 3) determine the contribution of oxidative peat decomposition to total subsidence, using the year-round field data.

\section{Material and methods \\ 2.1 Study site}

Soil $\mathrm{CO}_{2}$ efflux was measured in a rubber (Hevea brasiliensis) plantation $\left(02^{\circ} 29^{\prime} 50^{\prime \prime} \mathrm{S}\right.$, $\left.114^{\circ} 11^{\prime} 20^{\prime \prime} \mathrm{E}\right)$ on peat soil in Jabiren, Central Kalimantan, Indonesia, from December 2014 to December 2015. A strong El Niño event occurred in the period (Schiermeier, 2015). The peat depth was $5 \mathrm{~m}$ on average. The study site was originally a peat swamp forest, but was deforested and drained through MRP in the late 1990s. The site was abandoned after MRP and burnt by peat fire in El Niño years. In 2007, rubber trees were planted for latex harvest at intervals of $3 \mathrm{~m}$ and $6.5 \mathrm{~m}$ with intercropping pineapple plants between tree rows (Fig. 1) after peat compaction using heavy machinery. The age of rubber trees was eight years old, and the tree height was approximately $6 \mathrm{~m}$. Rubber trees defoliated in the dry season from June to November, which resulted in large accumulation of leaf litter on the ground. A combination of chemical and organic (manure) fertilizers

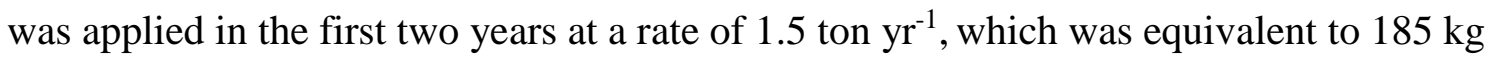
$\mathrm{N} \mathrm{ha}^{-1}$, $185 \mathrm{~kg} \mathrm{P}_{2} \mathrm{O}_{5} \mathrm{ha}^{-1}, 183 \mathrm{~kg} \mathrm{~K}_{2} \mathrm{O} \mathrm{ha}{ }^{-1}$ and $120 \mathrm{~kg} \mathrm{~S}^{-1}$, by piling up the fertilizer at tree bases. For the top 0.75-m-thick peat, bulk density (BD) was $0.23 \mathrm{~g} \mathrm{~cm}^{-3}$, C and 
nitrogen $(\mathrm{N})$ contents were $42.8 \%$ and $2.34 \%$, respectively, and consequently the $\mathrm{C} / \mathrm{N}$ ratio was 18.3. Mineral content showed an increase tendency below $0.5 \mathrm{~m}$ (detailed in Table 3). For the top 0.5 -m-thick peat, $\mathrm{pH}$ was 3.4 and 3.5, respectively, in the dry and wet seasons (personal communication).

\subsection{Experimental design}

To exclude root respiration and directly measure $\mathrm{CO}_{2}$ efflux through oxidative peat decomposition (PD), three square trenching plots with a respective area of $1 \times 1 \mathrm{~m}^{2}$ were established in June 2014, which were about $40 \mathrm{~m}$ distant from a drainage canal (Fig. 1). We began flux measurement six months after trenching, waiting for the calming of extra $\mathrm{CO}_{2}$ emissions through the decomposition of dead roots produced by trenching (Epron, 2009). Each plot was trenched $1 \mathrm{~m}$ deep into peat to cut roots, and then four plastic boards were inserted in four sides of trenches to prevent roots from invading into the plot. After trenching, four chamber bases were installed in each plot to avoid disturbing the peat surface when a chamber is set. For total soil respiration (SR), 12 chamber bases were distributed outside of the trenching plots. Tree roots are expected to be relatively localized around each tree, and root respiration depended on the distance from trees in an acacia plantation (Jauhiainen et al., 2012). Thus, the 12 chamber bases were aligned between tree rows with the same distance and categorized into two groups (near $(1.5 \mathrm{~m}$ ) and far (3 $\mathrm{m})$ positions) by the distance from rubber trees to examine the difference of root respiration (Fig. 1). Depth of insertion into peat soil was $3 \mathrm{~cm}$ in all chamber bases. SR reflects a combination of $\mathrm{PD}$, root respiration and the decomposition of leaf litter accumulating on the ground.

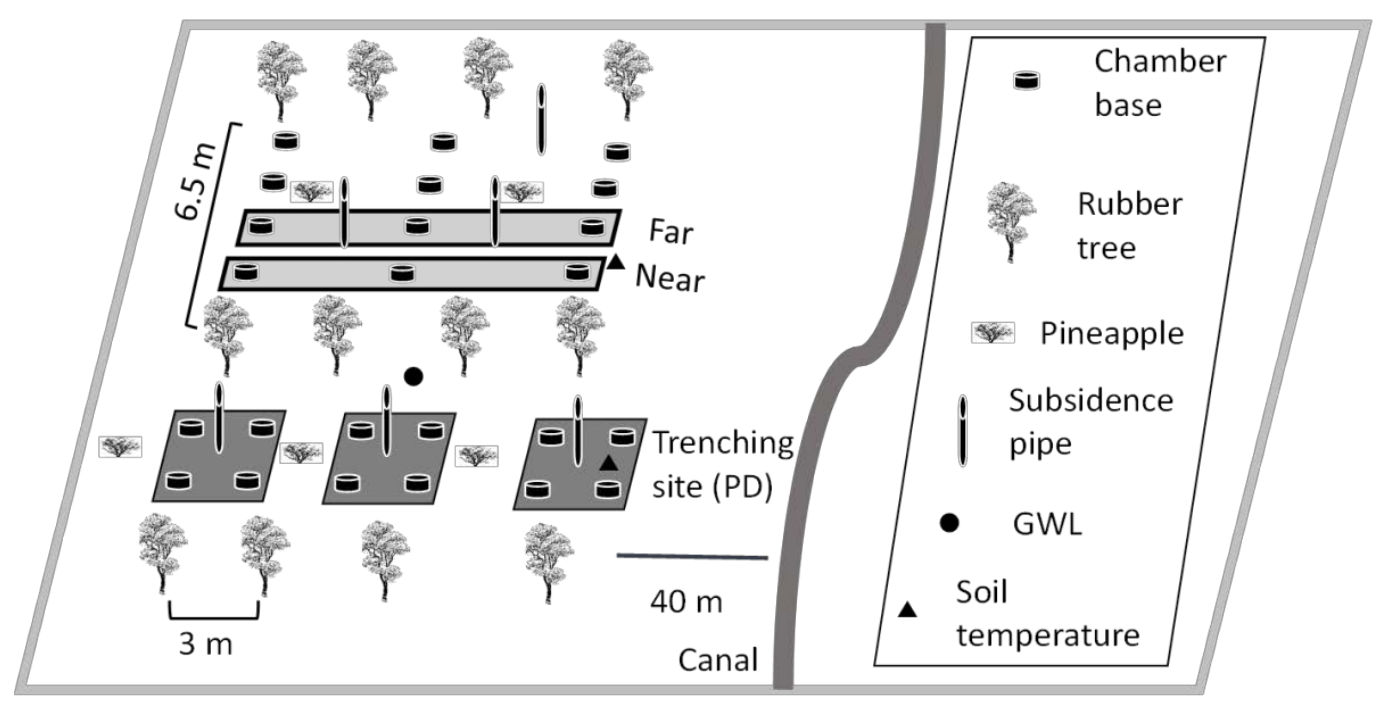

Fig. 1. Experimental plots and the distribution of chamber bases and ground sensors.

\subsection{Soil $\mathrm{CO}_{2}$ efflux measurement}


Soil $\mathrm{CO}_{2}$ efflux (PD and SR) was measured monthly on chamber bases using a closed chamber system, to which a portable infrared $\mathrm{CO}_{2}$ analyzer (GMP343, Vaisala, Helsinki, Finland), DC data logger (LR 5042, HIOKI, Nagano, Japan) and temperature data logger (LR5011, HIOKI) were installed. A chamber made of opaque PVC with $30 \mathrm{~cm}$ in diameter and $20 \mathrm{~cm}$ in height was employed. To improve the time response of the $\mathrm{CO}_{2}$ analyzer, we removed its filter and operated it in an open-path mode. The $\mathrm{CO}_{2}$ analyzer was calibrated every six months using standard gases. Throughout the study period, all plants were picked out from trenching plots, though understory plants were few in the plantation. Before measurement, leaf litter was removed from chamber bases in the trenching plots to exclude $\mathrm{CO}_{2}$ emissions through litter decomposition. Thus, the residual of $\mathrm{PD}$ in SR is equivalent to root respiration plus leaf-litter decomposition. The chamber and base were water-sealed after the chamber was ventilated using a fan. The base had a groove at the top to be filled with water.

Air temperature and $\mathrm{CO}_{2}$ concentration in chamber headspace were measured every 10 seconds for three minutes on each chamber base. Simultaneously, soil temperature was measured at a depth of $5 \mathrm{~cm}$ using a digital thermometer near chamber bases. To cover a considerable temperature range, the measurement was replicated three times a day (8:3010:30, 11:30-13:30 and 14:30-16:30). Soil $\mathrm{CO}_{2}$ efflux $\left(\mu \mathrm{mol} \mathrm{m} \mathrm{m}^{-2} \mathrm{~s}^{-1}\right)$ was calculated from air temperature $\left(T_{\mathrm{a}},{ }^{\circ} \mathrm{C}\right)$ and an increasing rate of $\mathrm{CO}_{2}$ concentration $\left(d C / d t, \mu \mathrm{mol} \mathrm{mol}^{-1} \mathrm{~s}^{-}\right.$ ${ }^{1}$ ) using the following equation:

$$
\mathrm{CO}_{2} \text { efflux }=(d C / d t) \cdot V /\left(V^{\prime} \cdot\left(273.2+T_{a}\right) / 273.2\right) / A
$$

where $V$ is chamber volume $\left(0.0144 \mathrm{~m}^{3}\right), V^{\prime}$ is molar volume of air at $0^{\circ} \mathrm{C}\left(0.0224 \mathrm{~m}^{3}\right.$ $\mathrm{mol}^{-1}$ ) and $A$ is covered ground area by the chamber $\left(0.0707 \mathrm{~m}^{2}\right) . d C / d t$ was determined from $\mathrm{CO}_{2}$ concentrations during the last two minutes of measurement using the leastsquare method. A linearity test was applied to control the quality of $d C / d t$ following Aguilos et al. (2013). Also, relative humidity was measured in the headspace with a small hygrometer (SHTDA-2, SysCom Inc., Tokyo, Japan) to quantify the effect of water vapor dilution on $\mathrm{CO}_{2}$ concentration (Harazono et al., 2015; Matsuura et al., 2011).

The effect of water vapor dilution was within $0.2 \%$. Thus, no correction was applied against the dilution effect. Soil $\mathrm{CO}_{2}$ efflux was not significantly different among three replications (morning, noon and afternoon) within a day on all chamber bases $(p>0.05)$. Thus, data from the three replications were averaged on each day for each chamber base. The daily means of PD were further averaged within each trenching plot including four chamber bases. Also, SR was separated into two groups (near and far positions from tree rows) and averaged in each group.

To analyze the effect of GWL on PD and SR, linear or non-linear regression, such as logarithmic fitting, was applied to each data set from three trenched plots (PD) and 12 chamber bases (SR). Using the fitted equation, annual soil $\mathrm{CO}_{2}$ efflux ( $\mathrm{g} \mathrm{C} \mathrm{m}^{-2} \mathrm{yr}^{-1}$ ) was calculated from hourly GWL data. Also, the mean of monthly measurements $\left(\mathrm{g} \mathrm{C} \mathrm{m}^{-2} \mathrm{~d}^{-}\right.$ ${ }^{1}$ ) was simply converted to annual $\mathrm{CO}_{2}$ efflux. The annual values were determined for 
each trenching or each chamber base to evaluate spatial variations in PD and SR.

\subsection{Subsidence}

Ground subsidence was determined from temporal change in peat surface elevation, which was measured simultaneously with the $\mathrm{CO}_{2}$ efflux measurement using steel pipes inserted vertically into peat and anchored firmly at underlying mineral substrate. Three steel pipes were installed inside and outside of the trenching, respectively (Fig. 1). Annual subsidence $\left(\mathrm{cm} \mathrm{yr}^{-1}\right)$ was determined as the difference in ground elevation between December 2014 and December 2015 during the flux measurement period. Because ground elevation depends on GWL independently of peat decomposition, subsidence should be corrected for GWL difference between the first and last dates to correctly apply the subsidence method. In this study, ground elevation was interpolated to the same GWL from a linear relationship between elevation and GWL, which was determined using short-term data (detailed in 3.5).

\subsection{Peat properties}

To analyze bulk density (BD) and carbon content, five peat samples were collected, respectively, at six depths from 0 to $75 \mathrm{~cm}$ in the dry season (September 2014), when GWL was $-0.88 \mathrm{~m}$. Peat samples were taken horizontally from a pit using $100-\mathrm{cm}^{3}$-large core samplers to prevent the sample from compression (Hooijer et al., 2012), excluding buried logs. The pit was excavated in the middle of rubber trees, where root density was expected to be minimal. Peat BD and volumetric water content was determined in a laboratory by a gravimetric method. Carbon content was determined using a CN analyzer (CNS-2000 elemental analyzer, LECO Corporation, Michigan, USA), along with nitrogen $(\mathrm{N})$ and sulfur $(\mathrm{S})$ content.

\subsection{Soil environment}

Groundwater level (GWL), which was defined as the relative elevation of the groundwater surface to the ground surface, was measured hourly at around the center of the study area (Fig. 1) using a water pressure sensor (Model HTV 050KP-10-V, Sensez Co., Tokyo, Japan) in a perforated PVC pipe inserted vertically deep into mineral soil. The ground was flat without any hummocks because of compaction. Soil temperature was recorded hourly using a temperature data logger (Thermochron SL type, KN laboratories, Osaka, Japan) installed at a depth of $5 \mathrm{~cm}$ both inside and outside of the trenching (Fig. 1). In addition, daily precipitation measured at Palangkaraya (Hirano et al., 2009), about $25 \mathrm{~km}$ distant from the study site, was used to know the precipitation pattern.

\subsection{Conversion of peat decomposition to subsidence}

The annual PD ( $\mathrm{g} \mathrm{C} \mathrm{m}^{-2} \mathrm{yr}^{-1}$ ) was converted into corresponding subsidence (PS, cm $\mathrm{yr}^{-1}$ ) using $\mathrm{BD}\left(\mathrm{g} \mathrm{cm}^{-3}\right)$ and carbon content (CC, \% in mass) using the following equation (Agus et al., 2011); 


$$
\mathrm{PS}=P D / B D / C C / 100
$$

\subsection{Statistical analysis}

One-way ANOVA and Pearson correlation analysis were conducted using R software (R Development Core Team 2015; version 3.1.3).

\section{Results}

\subsection{Seasonal variations in groundwater level and soil temperature}

During the flux measurement period from December 2014 to 2015, the dry season, which is commonly defined as months with monthly precipitation less than $100 \mathrm{~mm}$ (Hirano et al., 2015), lasted for four months from July through October (Fig. 2a). In particular, monthly precipitation was less than $5 \mathrm{~mm}$ in August and September. In spite of an El Niño drought, annual precipitation measured $2506 \mathrm{~mm} \mathrm{yr}^{-1}$, which was almost identical to the 14-year-long mean between 2002 and 2015 (2553 $\pm 465 \mathrm{~mm} \mathrm{yr}^{-1}$; mean \pm 1 standard deviation (SD)).

Mean annual GWL was $-0.69 \mathrm{~m}$ during the flux measurement period. GWL varied seasonally between -1.71 and $0.03 \mathrm{~m}$ (Fig. 2b). GWL was high in the wet season from December to May and low in the dry season from June to November following a seasonal variation in precipitation (Fig. 2a). In 2015, the minimum GWL was lower at $-1.71 \mathrm{~m}$ than in 2014 at $-1.35 \mathrm{~m}$ because of the prolonged dry season due to a strong El Nino event
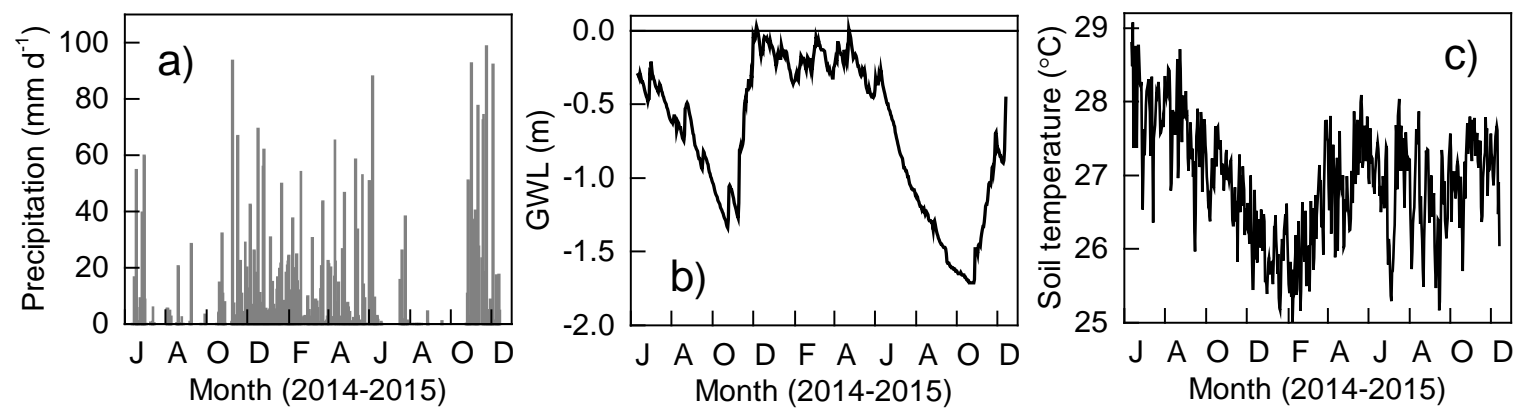

Fig. 2. Variations in daily values of (a) precipitation, (b) groundwater level (GWL) and

(c) mean soil temperature of inside and outside the trenching from June 2014 to December 2015. Precipitation was measured in Palangkaraya (Hirano et al., 2009), which was about $25 \mathrm{~km}$ distant from the study site.

Mean daily soil temperature ranged between 25 and $28^{\circ} \mathrm{C}$ during the flux measurement period. Mean annual soil temperatures inside and outside the trenching were 26.4 and $26.9^{\circ} \mathrm{C}$, respectively, with no significant difference $(p>0.05)$. Soil temperature showed a positive linearity with GWL $(p<0.05)$ in spite of low $r^{2}$ of 0.02 both inside and outside the trenching. 


\subsection{Seasonal variations in soil $\mathrm{CO}_{2}$ efflux}

PD showed a large seasonal variation and a negative correlation with GWL (Figs. 2b and 3a); PD increased up to about $10 \mathrm{~g} \mathrm{C} \mathrm{m}^{-2} \mathrm{~d}^{-1}$ in the dry season and remained low at 0-2 $\mathrm{g} \mathrm{C} \mathrm{m}^{-2} \mathrm{~d}^{-1}$ during the wet season. Although GWL was lowest in late October 2015 (Fig. 2b), the highest PD was measured in November, just after the first considerable precipitation event in the coming wet season (Fig. 2a). In contrast, seasonal variation in SR was small after February (Fig. 3b). PD averaged at $3.98 \pm 0.39 \mathrm{~g} \mathrm{C} \mathrm{m}^{-2} \mathrm{~d}^{-1}( \pm 1$ standard deviation (SD), $n=3$ ), whereas SR averaged at $8.61 \pm 2.92$ and $8.19 \pm 2.16 \mathrm{~g} \mathrm{C} \mathrm{m}^{-2} \mathrm{~d}^{-1}$, respectively, at near and far positions $(n=6)$; the two means of SR were not significantly different $(p>0.05)$. The residual between the means of SR and PD showed a different
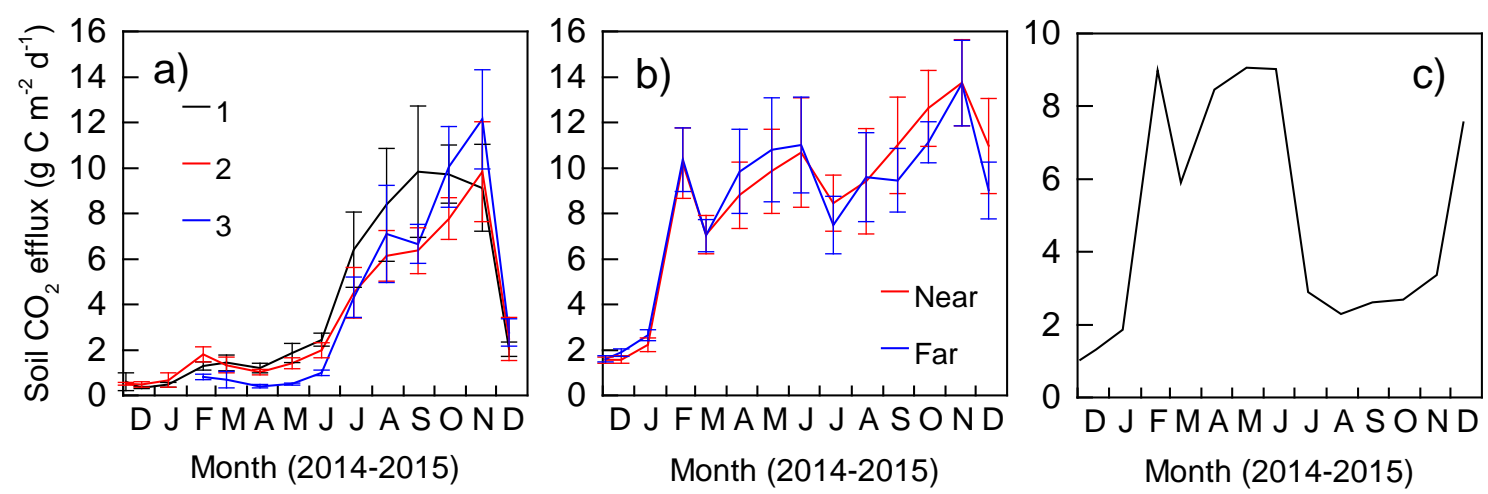

275

276

277

278

279

280

281

282

283

284

285

286

287

288

289

290

291

292

Fig. 3. Seasonal variations in daily mean (a) peat decomposition (PD, three trenching plots, $n=4$ ), (b) total soil respiration (SR, near and far positions from tree rows, $n=$ 6) and (c) residual between means of SR and PD from December 2014 to December 2015. Vertical bars in (a) and (b) denote 1 standard error (SE).

\subsection{Relationships of soil $\mathrm{CO}_{2}$ efflux with soil environmental factors}

The relationship between PD and soil temperature was not significant $\left(p>0.05, r^{2}=\right.$ $0.04)$, whereas SR showed significant positive correlation with soil temperature $(p<0.01)$, but $r^{2}$ was low at 0.06 . On the other hand, although PD increased linearly as GWL lowered $(p<0.001$, Fig. 4), SR increased logarithmically with GWL lowering both at near and far position ( $p<0.01$, Fig. 5). For PD, the regression was improved in all trenching plots $\left(r^{2}\right.$ $=0.94-0.98$ ) when the data in November 2015 were excluded, because the data were most probably pulse-like instantaneous $\mathrm{CO}_{2}$ efflux and were caused by a considerable amount of rain at the beginning of the wet season after a severe drought (Lee et al., 2004). If daily data are averaged within the three plots, correlation is expressed as PD $\left(\mathrm{g} \mathrm{C} \mathrm{m}^{-2} \mathrm{~d}^{-1}\right)=$ $0.04-5.40 \times$ GWL $(\mathrm{m})\left(r^{2}=0.99\right)$. This equation suggests that every lowering of GWL by $0.1 \mathrm{~m}$ causes additional PD of $0.54 \mathrm{~g} \mathrm{C} \mathrm{m}^{-2} \mathrm{~d}^{-1}$, and PD becomes almost zero when GWL rises up to $0 \mathrm{~m}$. 


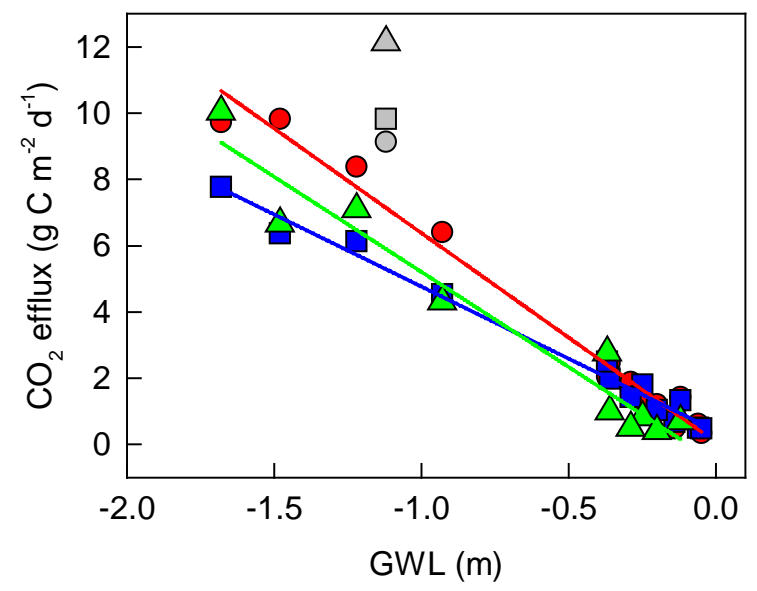

Fig. 4. Relationship between peat decomposition (PD) and groundwater level (GWL) in trenching 1 (circles), 2 (squares) and 3 (triangles). Each symbol denotes a daily average $(n=4)$. A grey symbol denotes November's measurement. A line is fitted without the grey symbol for each trenching $(p<0.001)$ : 1) $y=0.07-6.31 \cdot x\left(r^{2}=\right.$ $0.98)$, 2) $\left.y=0.41-4.35 \cdot x\left(r^{2}=0.98\right), 3\right) y=-0.53-5.74 \cdot x\left(r^{2}=0.94\right)$

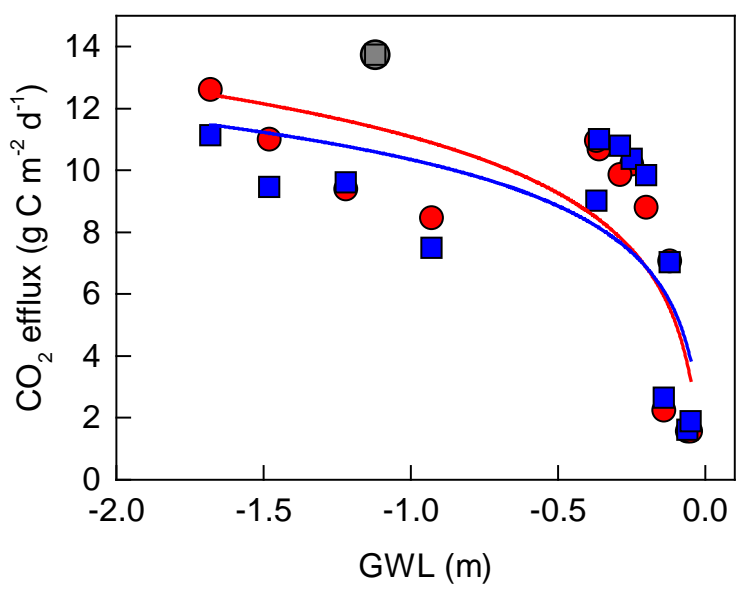

Fig. 5. Relationship between total soil respiration (SR) and groundwater level (GWL) for near (circles) and far (squares) positions from tree rows. Each symbol denotes a daily average $(n=6)$. A grey symbol denotes November's measurement. A logarithmic curve is fitted without the grey symbol for each position $(p<0.01)$ : near) $y=11.1-2.63 \cdot \ln (-x)\left(r^{2}=0.61\right)$, far $y=10.4-2.17 \cdot \ln (-x)\left(r^{2}=0.47\right)$.

\subsection{Annual $\mathrm{CO}_{2}$ emissions}

Annual soil $\mathrm{CO}_{2}$ emissions ( $\left(\mathrm{g} \mathrm{C} \mathrm{m}^{-2} \mathrm{yr}^{-1}\right.$ ) from December 2014 to December 2015 were calculated from hourly GWL data (Fig. 2b) for each trenching plot (PD) and chamber base (SR), respectively, using the linear (Fig. 4) or logarithmic (Fig. 5) relationships; data in November 2015 were excluded. Also, mean annual soil $\mathrm{CO}_{2}$ efflux ( $\left(\mathrm{C} \mathrm{m}^{-2} \mathrm{~d}^{-1}\right.$ ), including the November's data, was simply converted into annual $\mathrm{CO}_{2}$ 
312 emissions (Table 1). Annual $\mathrm{CO}_{2}$ emissions of PD were $1408 \pm 214$ and $1454 \pm 144 \mathrm{~g} \mathrm{C}$ $313 \mathrm{~m}^{-2} \mathrm{yr}^{-1}$, whereas those of SR were $3293 \pm 1039$ and $3068 \pm 899 \mathrm{~g} \mathrm{C} \mathrm{m}^{-2} \mathrm{yr}^{-1}$. There was 314 no significant difference between the two methods $(p>0.05)$ both for PD and SR. SR 315 was not significantly different between near and far positions from tree rows $(p>0.05)$. 316 On the other hand, we confirmed that SR was significantly larger than $\operatorname{PD}(p<0.001)$. 317 The residual of SR from PD was 1614-1885 $\mathrm{g} \mathrm{C} \mathrm{m}^{-2} \mathrm{yr}^{-1}$, which corresponds to the annual 318 sum of root respiration and leaf litter decomposition. PD accounted for $43-47 \%$ of SR on an annual basis.

Table 1. Annual $\mathrm{CO}_{2}$ emissions estimated using two methods (mean $\pm 1 \mathrm{SD}$ ).

\begin{tabular}{lcc}
\hline \multicolumn{1}{c}{ Treatment } & $\begin{array}{c}\text { Annual } \mathrm{CO}_{2} \text { emissions from } \\
\text { groundwater level } \\
\left(\mathrm{g} \mathrm{C} \mathrm{m}^{-2} \mathrm{yr}^{-1}\right)\end{array}$ & $\begin{array}{c}\text { Annual } \mathrm{CO}_{2} \text { emissions from } \\
\text { mean efflux } \\
\left(\mathrm{g} \mathrm{C} \mathrm{m}^{-2} \mathrm{yr}^{-1}\right)\end{array}$ \\
\hline PD & 1655 & 1556 \\
Trenching 1 & 1278 & 1290 \\
Trenching 2 & 1289 & 1516 \\
Trenching 3 & $1408 \pm 214$ & $1454 \pm 144$ \\
Mean $(n=3)^{\mathrm{a}}$ & & $3144 \pm 1068$ \\
\hline SR & $3398 \pm 1266$ & $2991 \pm 788$ \\
Near position $(n=6)$ & $3187 \pm 864$ & $3068 \pm 899$ \\
Far position $(n=6)$ & $3293 \pm 1039$ & 1614 \\
Mean $(n=12)^{\mathrm{b}}$ & 1885 & \\
\hline Residual $(\mathrm{b}-\mathrm{a})$ & &
\end{tabular}

322

\subsection{Contribution of peat decomposition to total subsidence}

Elevation of the peat surface basically varied in parallel to GWL (Fig. 6) with a significant positive relationship ( $p<0.001$ ), though it showed a hysteresis (data not shown). Even at the same GWL, the elevation was lower in the early wet season when GWL was rising than in the early dry season when GWL was lowering. The hysteresis reflects oxidative pet decomposition during the dry season with low GWL, leading to irreversible subsidence.

Peat surface elevation relative to the initial value in June 2014 was $0.72 \pm 0.72$ and $0.20 \pm 1.19 \mathrm{~cm}$ (mean $\pm 1 \mathrm{SD}, n=3$ ) for outside and inside trenching, respectively, on December 4, 2014, and $-8.11 \pm 3.51$ and $-8.99 \pm 1.11 \mathrm{~cm}$, respectively, on December 13, 2015. As the difference in elevation, annual subsidence was calculated to be $8.61 \pm 3.20$ and $8.58 \pm 0.43 \mathrm{~cm} \mathrm{yr}^{-1}$, respectively, for outside and inside trenching after adjusting the number of days (from 374 to 365 days). However, the annual subsidence was most likely overestimated, because GWL was higher by $0.31 \mathrm{~m}$ on December 4, 2014 (-0.06 m) than on December 13, 2015 (-0.37 m). Lower GWL potentially results in lower elevation independently of peat decomposition. Thus, the measured elevation on the initial day was 
linearly interpolated for GWL of $-0.37 \mathrm{~m}$. The sensitivities of elevation to GWL, which were calculated from three consecutive data from mid-November to mid-December 2014, were 10.0 and $8.8 \mathrm{~cm} \mathrm{~m}^{-1}$, respectively, for outside and inside trenching. As a result, the corrected annual rates of subsidence were $5.64 \pm 3.20$ and $5.96 \pm 0.43 \mathrm{~cm} \mathrm{yr}^{-1}$ for outside and inside trenching, respectively; the corrected annual subsidence was 5.36, 6.29 and $6.24 \mathrm{~cm} \mathrm{yr}^{-1}$, respectively, in the trenching 1, 2 and 3. There was no significant difference in annual subsidence between inside and outside ( $p>0.05)$.

To quantify the contribution of oxidative peat decomposition to the subsidence, firstly, annual PD estimated from hourly GWL $\left(1408 \pm 214 \mathrm{~g} \mathrm{C} \mathrm{m}^{-2} \mathrm{yr}^{-1}\right)$ (Table 1) was converted to subsidence using BD and carbon content of peat at different depths (Table 2), based on a simple assumption that the peat oxidation occurred only at each depth. Because BD and carbon content varied vertically, subsidence through PD ranged from 1.13-1.18 $\mathrm{cm} \mathrm{yr}^{-1}$ at depth of $10-25 \mathrm{~cm}$ to $1.92 \mathrm{~cm} \mathrm{yr}^{-1}$ in the top layer $(0-5 \mathrm{~cm})$. The PD subsidence averaged at $1.50 \mathrm{~cm} \mathrm{yr}^{-1}$ and accounted for $25 \%$ of total subsidence inside trenching ( $5.96 \mathrm{~cm} \mathrm{yr}^{-1}$ ) on average.

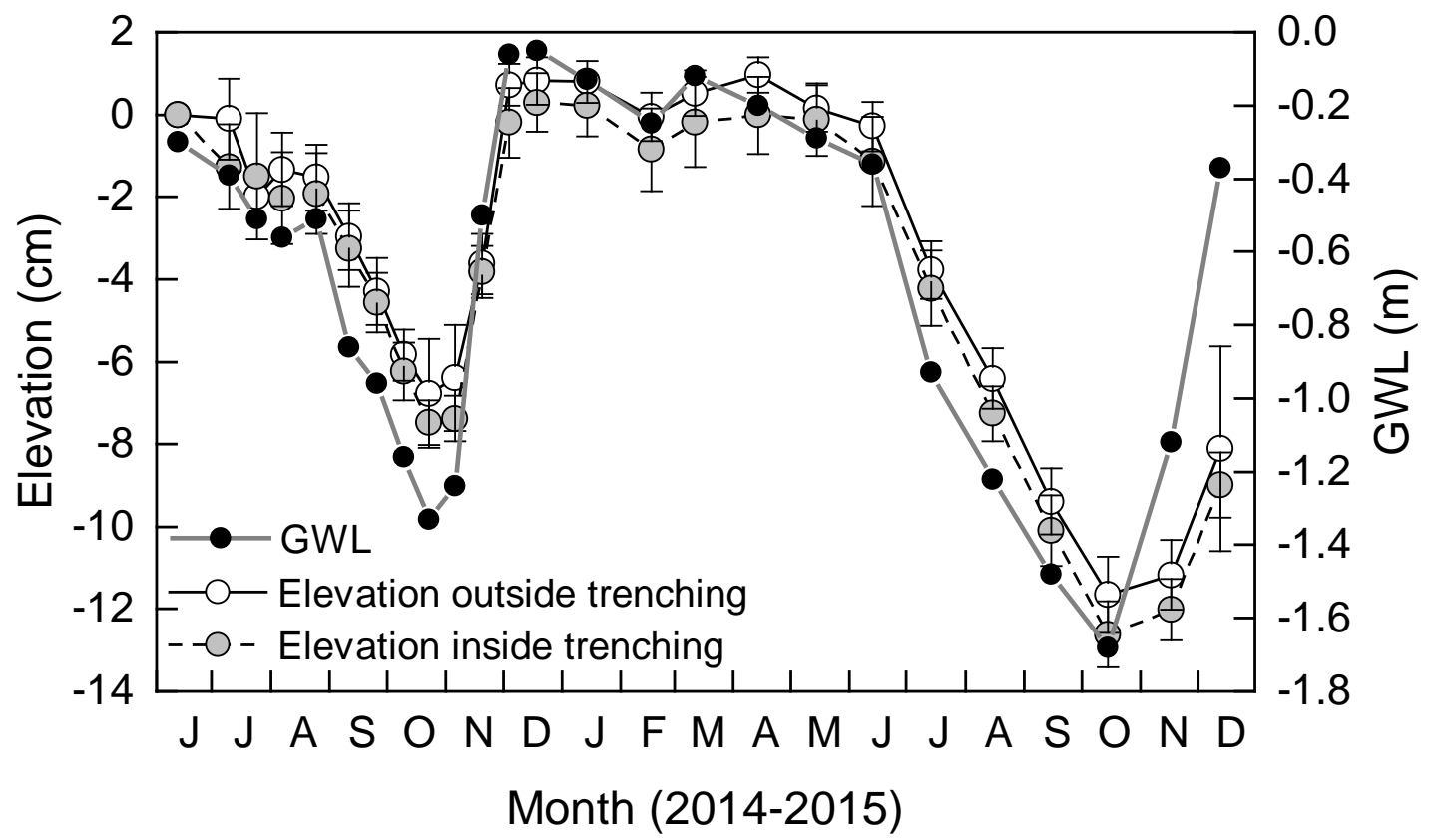

355

356

357

358

359

360

361

362

363

Fig. 6. Seasonal variations in peat surface elevation and groundwater level (GWL) from June 2014 through December 2015. Mean elevation $(n=3)$ is shown relatively to that in June 2014. Vertical bars denote 1 standard deviation.

Table 2. Peat properties and annual subsidence through oxidative peat decomposition (PD). Annual PD estimated from hourly groundwater levels (GWL) was converted to annual subsidence using bulk density (BD) and carbon content of peat at different depths. For BD and soil water content, mean $\pm 1 \mathrm{SD}(n=5)$ is shown at 

2014, when GWL was $-0.88 \mathrm{~m}$.

367

\begin{tabular}{|c|c|c|c|c|c|c|c|c|}
\hline $\begin{array}{l}\text { Annual } \\
\text { PD } \\
\left(\mathrm{g} \mathrm{C} \mathrm{m}^{-2}\right. \\
\left.\mathrm{yr}^{-1}\right)\end{array}$ & $\begin{array}{l}\text { Peat } \\
\text { depth } \\
(\mathrm{cm})\end{array}$ & $\begin{array}{c}\mathrm{BD} \\
\left(\mathrm{g} \mathrm{cm}^{-3}\right)\end{array}$ & $\begin{array}{c}\text { Carbon } \\
\text { content } \\
(\%)\end{array}$ & $\begin{array}{c}\text { Nitrogen } \\
\text { content } \\
\text { (\%) }\end{array}$ & $\begin{array}{l}\text { Sulfur } \\
\text { content } \\
(\%)\end{array}$ & $\begin{array}{c}\text { Soil water } \\
\text { content }\left(\mathrm{m}^{3}\right. \\
\left.\mathrm{m}^{-3}\right)\end{array}$ & $\begin{array}{l}\text { Subsidence } \\
\text { through PD } \\
\left(\mathrm{cm} \mathrm{yr}^{-1}\right)\end{array}$ & $\begin{array}{c}\text { Total } \\
\text { subsidence } \\
\left(\mathrm{cm} \mathrm{yr}^{-1}\right)\end{array}$ \\
\hline \multirow{7}{*}{$\begin{array}{c}1408 \pm \\
214\end{array}$} & $0-5$ & $\begin{array}{c}0.24 \pm \\
0.02\end{array}$ & 30.5 & 1.79 & 0.37 & $\begin{array}{c}0.34 \pm \\
0.05\end{array}$ & $1.92 \pm 0.24$ & \multirow{7}{*}{$5.96 \pm 0.43$} \\
\hline & $5-10$ & $\begin{array}{c}0.20 \pm \\
0.03\end{array}$ & 53.3 & 2.65 & 0.63 & $\begin{array}{c}0.42 \pm \\
0.03\end{array}$ & $1.32 \pm 0.16$ & \\
\hline & $10-15$ & $\begin{array}{c}0.23 \pm \\
0.04\end{array}$ & 51.7 & 2.28 & 0.64 & $\begin{array}{c}0.53 \pm \\
0.06\end{array}$ & $1.18 \pm 0.15$ & \\
\hline & $20-25$ & $\begin{array}{c}0.23 \pm \\
0.05\end{array}$ & 54.0 & 1.98 & 0.61 & $\begin{array}{c}0.65 \pm \\
0.05\end{array}$ & $1.13 \pm 0.14$ & \\
\hline & $50-55$ & $\begin{array}{c}0.25 \pm \\
0.06\end{array}$ & 33.0 & 2.92 & 0.04 & $\begin{array}{c}0.70 \pm \\
0.05\end{array}$ & $1.71 \pm 0.21$ & \\
\hline & $70-75$ & $\begin{array}{c}0.24 \pm \\
0.08\end{array}$ & 34.1 & 2.41 & 0.06 & $\begin{array}{c}0.77 \pm \\
0.06\end{array}$ & $1.72 \pm 0.21$ & \\
\hline & $\begin{array}{c}\text { Mean } \pm 1 \\
\text { SD }\end{array}$ & $\begin{array}{c}0.23 \pm \\
0.05\end{array}$ & $\begin{array}{c}42.8 \pm \\
11.3\end{array}$ & $\begin{array}{c}2.34 \pm \\
0.38\end{array}$ & $\begin{array}{c}0.39 \pm \\
0.26\end{array}$ & $\begin{array}{c}0.57 \pm \\
0.16\end{array}$ & $1.50 \pm 0.30$ & \\
\hline
\end{tabular}

\section{Discussion}

\subsection{Controls on soil $\mathrm{CO}_{2}$ efflux}

The trenching method was applied to separate oxidative peat decomposition (PD)

372 from total soil respiration (SR). Although the trenching method has been widely applied, 373 the method has limitations and shortcomings (Epron, 2009; Hanson et al., 2000; Subke et 374 al., 2006) due to insufficient trenching depth, the decomposition of cut roots remaining in 375 trenched plots, no supply of root litter through mortality and soil moisture rise caused by 376 no transpiration. In this study, we trenched $1 \mathrm{~m}$ deep into peat at the middle of tree rows 377 (Fig. 1) six months before the beginning of chamber measurement. A study on the fine378 root dynamics of rubber trees on mineral soil in northern Thailand reported that fine roots 379 concentrated in shallow soil of 0.0-0.5 m (Maeght et al., 2015). Also, the duration, during 380 which GWL was below $1 \mathrm{~m}$, was limited except for in strong El Niño years (Fig. 2b). 381 Thus, the trenching depth of $1 \mathrm{~m}$ would be sufficient in this site to avoid lateral root 382 invasion. As for the decomposition of cut roots, during the six month after trenching 383 including the dry season with low GWL (Fig. 2b), the majority of dead fine roots was 384 expected to be decomposed (Comeau et at, 2016), though some, including dead coarse 385 roots, were possibly still left and kept decomposing. The ongoing decomposition 
potentially led to the overestimation of PD. In contrast, the absence of live roots decreases heterotrophic respiration because of no root-litter input. However, this disturbance of no root-litter decomposition is preferable to measure PD. Although no data were available on soil moisture, if soil moisture was higher in trenched plots under low GWL conditions, microbial respiration was potentially enhanced (Ishikura et al., 2016), which could overestimate PD.

Both SR and PD were significantly depended on GWL (Figs. 4 and 5). In the wet season from December 2014 to June 2015, PD was consistently low because of high GWL near the ground surface. Such high GWL made an anoxic condition in the whole soil profile by preventing oxygen penetrating into the soil because of water saturation and consequently impeded the organic material decomposition (Hirano et al., 2009; Husen et al., 2014). In the dry season, PD increased gradually as GWL dropped deeply in unsaturated conditions and resultant high oxygen availability in the peat soil profile (Inubushi et al., 2003; Jauhiainen et al., 2005; Iiyama and Osawa, 2010). There are several studies on the relationship of soil $\mathrm{CO}_{2}$ efflux with GWL in tropical peatland (Itoh et al., 2012; Sundari et al., 2012; Comeau et al., 2013; Hirano et al., 2014; Carlson et al., 2015; Ishikura et al., 2016). In this study, PD showed a strong negative linearity with GWL (Fig. 4), partly because GWL was lowered much by a strong El Niño drought of 2015 (Fig. 2b). Kwon et al. (2013) found that in drained peatlands, such as plantations, peat carbon was more vulnerable to drought events than in pristine peatlands. The peak of PD was measured in November, just after a lot of rain at the beginning of the wet season (Figs. 2a and 3a) probably because of stimulated microbial activity by the rain (Lee et al., 2004). In semiarid and arid ecosystems, shallowly infiltrating rain water increased microbial respiration after a prolonged dry period (Huxman et al., 2004).

The relationship between soil $\mathrm{CO}_{2}$ efflux and soil temperature was significant $(p<$ $0.01)$, but with low $r^{2}(0.06)$, for SR or not significant $(p>0.05)$ for PD. In addition, although soil temperature was usually higher in the afternoon, soil $\mathrm{CO}_{2}$ efflux was not significantly different among three replications within a day $(p>0.05)$. The low temperature sensitivity of soil $\mathrm{CO}_{2}$ efflux was attributable to the small amplitude of soil temperature both on annual (Fig. 2c) and daily bases under the tree canopy. In open peat areas, however, soil temperature positively affected soil $\mathrm{CO}_{2}$ efflux (Schrier-Uijl et al., 2013; Jauhiainen et al.,2014). On the other hand, Hirano et al. (2014) found that the effect of soil temperature rise on soil $\mathrm{CO}_{2}$ efflux was small even at an open peatland when GWL was low.

The residual of SR from PD, which corresponds to root respiration and leaf litter decomposition, increased in the wet season from February to June 2015 (Fig. 3c), when GWL was high near the ground surface (Fig. 2b). The seasonal variation suggests the phenology of root growth and the enhancement of litter decomposition in the wet season. The root activity of rubber trees would be positively related to the production of latex, which is higher in the wet season (Verheye, 2010). Maeght et al. (2015) found that fine roots of rubber trees began to grow three months after the beginning of the wet season, 
427 though it was a research on mineral soil. In addition, the decomposition of leaf litter was 428 enhanced in the wet season in tropical peat swamp forests (Sundari et al., 2012). In 429 contrast, the residual was low in the dry season. The dry soil condition probably depressed 430 root activity. Also, rubber trees have an annual vegetative cycle with defoliation called 431 "wintering” in the dry season (Verheye, 2010). Although the defoliation resulted in more 432 litter accumulation in this period, litter decomposition was depressed by the desiccation 433 condition (Hirano et al., 2009).

434

\subsection{Annual $\mathrm{CO}_{2}$ emissions}

436

Annual soil $\mathrm{CO}_{2}$ emissions were calculated in two manners. The significant relationships with GWL (Figs. 3 and 4) suggest that annual emissions calculated from 438 hourly GWL are more reliable than those by averaging, though the former would be 439 potentially underestimated to some extent because of the exclusion of pulse-like $\mathrm{CO}_{2}$ 440 efflux due to a rain event (Lee et al., 2004). The annual PD estimated from hourly GWL $441 \quad\left(1408 \pm 214 \mathrm{~g} \mathrm{C} \mathrm{m}^{-2} \mathrm{yr}^{-1}\right)$ was compared with those measured at various land-use types in 442 tropical peatlands (Table 3). Within plantations, our PD result was much lower than that 443 of an acacia plantation with lower mean annual GWL in Sumatra, Indonesia (Jauhiainen 444 et al., 2012). This is possibly because acacia trees could change the soil properties by 445 increasing the level of organic carbon and total nitrogen, resulting in higher microbial 446 biomass and basal respiration (Hergoualc'h and Verchot, 2013; Marchante et al., 2008). 447 Our result was also lower than that of an oil palm plantation and the bare ground after 448 deforestation (Husnain et al., 2014), but higher than those of different oil palm plantations 449 in Sumatra (Dariah et al., 2013) and Sarawak, Malaysia (Melling et al., 2013). On the 450 other hand, our result was the same as PD in a rubber plantation in Sumatra (Husnain et 451 al., 2014). To assess the annual PD, Dariah et al. (2014), Husnain et al. (2014) and Melling 452 et al. (2013) averaged periodic flux measurements, whereas Jauhiainen et al. (2012) 453 calculated it from monthly or quarterly GWL data using a negative linear equation. Also, 454 Hirano et al. (2014) calculated the annual PD from half-hourly GWL data using a negative 455 logarithmic equation determined using continuous $\mathrm{CO}_{2}$ efflux data. 
Table 3. Comparison of annual $\mathrm{CO}_{2}$ emissions through oxidative peat decomposition (PD) with previous studies using the chamber method.

\begin{tabular}{|c|c|c|c|c|c|}
\hline $\begin{array}{l}\text { Land-use } \\
\text { type }\end{array}$ & $\begin{array}{c}\mathrm{CO}_{2} \text { emissions } \\
\left(\mathrm{g} \mathrm{C} \mathrm{m}^{-2} \mathrm{yr}^{-1}\right)\end{array}$ & $\begin{array}{l}\text { Mean groundwater } \\
\text { level (m) }\end{array}$ & Treatment & Reference & Note \\
\hline $\begin{array}{l}\text { Oil palm } \\
\text { plantation }\end{array}$ & 1042 & -0.52 & Inter-rows & $\begin{array}{l}\text { Dariah et al., } \\
2014\end{array}$ & Six years old \\
\hline $\begin{array}{l}\text { Oil palm } \\
\text { plantation }\end{array}$ & 930 & -1.14 & Inter-rows & $\begin{array}{c}\text { Dariah et al., } \\
2014\end{array}$ & 15 years old \\
\hline $\begin{array}{l}\text { Oil palm } \\
\text { plantation }\end{array}$ & 1800 & -0.72 & Inter-rows & $\begin{array}{l}\text { Husnain et al., } \\
2014\end{array}$ & \\
\hline $\begin{array}{l}\text { Oil palm } \\
\text { plantation }\end{array}$ & 693 & -0.58 & Trenching & $\begin{array}{c}\text { Melling et al., } \\
2013\end{array}$ & $\begin{array}{l}\text { Including leaf litter } \\
\text { decomposition }\end{array}$ \\
\hline $\begin{array}{l}\text { Acacia } \\
\text { plantation }\end{array}$ & 2182 & -0.80 & $\begin{array}{l}\text { Trenching \& } \\
\text { Inter-rows }\end{array}$ & $\begin{array}{c}\text { Januhiainen et } \\
\text { al., } 2012\end{array}$ & $\begin{array}{l}\text { Corrected for soil } \\
\text { temperature }\end{array}$ \\
\hline $\begin{array}{l}\text { Sago } \\
\text { plantation }\end{array}$ & 762 & -0.24 & Trenching & $\begin{array}{c}\text { Melling et al., } \\
2013\end{array}$ & $\begin{array}{l}\text { Including leaf litter } \\
\text { decomposition }\end{array}$ \\
\hline $\begin{array}{l}\text { Rubber } \\
\text { plantation }\end{array}$ & 1418 & -0.67 & Inter-rows & $\begin{array}{l}\text { Husnain et al., } \\
2014\end{array}$ & \\
\hline $\begin{array}{l}\text { Bare } \\
\text { ground }\end{array}$ & 1718 & -0.70 & Inter-rows & $\begin{array}{c}\text { Husnain et al., } \\
2014\end{array}$ & $\begin{array}{l}\text { Plantations after } \\
\text { harvesting }\end{array}$ \\
\hline $\begin{array}{l}\text { Mixed } \\
\text { forest }\end{array}$ & 993 & -0.46 & Trenching & $\begin{array}{l}\text { Melling et al., } \\
2013\end{array}$ & $\begin{array}{l}\text { Including leaf litter } \\
\text { decomposition }\end{array}$ \\
\hline Burnt forest & 372 & -0.14 & Burning & $\begin{array}{l}\text { Hirano et al., } \\
2014\end{array}$ & \\
\hline $\begin{array}{l}\text { Rubber } \\
\text { plantation }\end{array}$ & 1408 & -0.69 & Trenching & This study & \\
\hline
\end{tabular}

In this study, PD accounted for 43\% of SR (3293 $\mathrm{g} \mathrm{C} \mathrm{m}^{-2} \mathrm{yr}^{-1}$ ) on an annual basis (Table 1). Nurzakiah et al. (2014) measured SR using a static chamber system in a nearby rubber plantation for 10 months in 2013. The mean of monthly measurements was equivalent to $723 \mathrm{~g} \mathrm{C} \mathrm{m}^{-2} \mathrm{yr}^{-1}$, which was much lower than our result. The low SR was due to the static chamber method with long closing time of 24 min, during which $\mathrm{CO}_{2}$ concentration in the chamber headspace was probably almost saturated (e.g. Nakano et al., 2004). The contribution of PD was much lower than those of mature acacia (79\%, Jauhiainen et al., 2012) and oil palm (71-86\%, Dariah et al., 2013) plantations in Sumatra. On the other hand, the contribution of the residual ( $\mathrm{SR}-\mathrm{PD}=1885 \mathrm{~g} \mathrm{C} \mathrm{m}^{-2} \mathrm{yr}^{-1}$ ), which corresponds to root respiration (RR) and the decomposition of leaf litter (LD), to SR was $57 \%$ on an annual basis (Table 1). However, the contribution of LD would have been small or negligible in plantations (Jauhiainen et al., 2012; Nagano et al., 2013). Alternatively, Hergoualc'h and verchot (2011) estimated that carbon inputs through litter 
fall was 150 and $510 \mathrm{~g} \mathrm{C} \mathrm{m}^{-2} \mathrm{yr}^{-1}$ in oil palm and acacia plantations, respectively. Assuming that the litter fall at the rubber plantation was equivalent to the average (330 $\mathrm{g}$ $\mathrm{C} \mathrm{m}^{-2} \mathrm{yr}^{-1}$ ) of the two values and the litter fall was all decomposed in a year, annual RR is calculated to be $1555 \mathrm{~g} \mathrm{C} \mathrm{m}^{-2} \mathrm{yr}^{-1}$ or $47 \%$ of SR. This RR contribution was much higher than those of acacia (21\%, Jauhiainen et al., 2012) and oil palm plantations in Sumatra (17-29\%, Dariah et al., 2013), but lower than a mixed swamp forest (60\%), oil palm plantation (62\%) and sago plantation (52\%) in Sarawak (Melling et al., 2013).

SR was measured at near and far positions from rubber trees to examine the spatial distribution of RR. It is reported that SR depends on distances from trees and is expected to be free of RR contribution at far positions in acacia and oil palm plantations (Jauhiainen et al., 2012; Dariah et al., 2013). Unexpectedly, however, no significant difference was found in SR between at near and far positions from rubber trees ( $p>0.05$ ) (Table 2). This result indicates that $\mathrm{RR}$ did not decrease with a distance from trees up to $3 \mathrm{~m}$, around the middle of tree rows. Roots of rubber trees could explore and intermingle in the inter-space of tree rows by seven years after planting (Pathiratna, 2006). Moreover, the compacted peat condition in this site probably enhanced root development (Melling et al., 2013). A large standard deviation (SD) in SR in comparison with PD (Table 1) suggests a large spatial variation in RR.

This study was conducted in a strong El Niño year of 2015, in which the dry season was prolonged, and GWL lowered more. Thus, PD was expected to be larger than in normal years without El Niño drought. To assess the effect of the El Niño drought in 2015, PD was calculated from GWL data during the dry seasons (June to November) in 2014 and 2015 using the linear relationships (Fig. 4). Mean seasonal GWL was lower by 0.35 $\mathrm{m}$ in 2015 than in 2014, a weak El Niño year. Seasonal PD was 675 and $1139 \mathrm{~g} \mathrm{C} \mathrm{m}^{-2}$, respectively, for 2014 and 2015; the latter was about 70\% higher than the former.

\subsection{Contribution of peat decomposition to total subsidence}

After correction for GWL variation, annual subsidence rates of $5.64 \pm 3.20$ and 5.96 $\pm 0.43 \mathrm{~cm} \mathrm{yr}^{-1}$ were found from outside and inside of trenching, respectively, during an El Niño year from December 2014 to December 2015. The rubber plantation had been drained for more than eight years, and the mean annual GWL was $-0.69 \mathrm{~m}$. Because ground elevation was sensitive to GWL (Fig. 6), elevation should be measured at short intervals simultaneously with GWL monitoring to determine annual subsidence correctly. The annual subsidence was higher than those measured at other plantations on tropical peat. For example, annual subsidence rates at acacia and oil palm plantations in Sumatra with mean annual GWL of $-0.70 \mathrm{~m}$ were 4.2 and $5 \mathrm{~cm} \mathrm{yr}^{-1}$, respectively, more than five years after initial drainage began (Couwenberg and Hooijer, 2013; Hooijer et al., 2012).

511 Using field data for more than 20 years, Nagano et al. (2013) reported that annual 512 subsidence was in the range of $3.1-5.2 \mathrm{~cm} \mathrm{yr}^{-1}$ in degraded peatland with mean GWL of $513-0.6 \mathrm{~m}$. In addition, mean annual subsidence rates of 2 and $3 \mathrm{~cm} \mathrm{yr}^{-1}$ were reported for a 514 drained peatland and an agricultural field in Malaysia, respectively (Wosten et al., 1997; 
515 Murayama and Bakar, 1996a). The larger subsidence in this study is attributable to low 516 GWL caused by the strong El Niño drought.

517 Annual subsidence resulting from oxidative peat decomposition (1408 $\mathrm{g} \mathrm{C} \mathrm{m}^{-2} \mathrm{yr}^{-1}$ ) 518 was simply calculated to be $1.50 \mathrm{~cm} \mathrm{yr}^{-1}$, which accounted for $25 \%$ of total subsidence of $5195.96 \mathrm{~cm} \mathrm{yr}^{-1}$ in the trenching (Table 2). The linear relationship of PD with GWL (Fig. 4) 520 suggests that peat oxidation intensity was almost evenly distributed in the unsaturated 521 peat layer above GWL. Thus, the PD from each peat depth can be proportional to the slice 522 area of a GWL $\times$ day horizon (Fig. 2b). In consideration of GWL variation, annual 523 oxidative subsidence was calculated to be $1.53 \pm 0.19 \mathrm{~cm} \mathrm{yr}^{-1}(n=3$, mean $\pm 1 \mathrm{SD})$ under an assumption that BD and carbon content below $75 \mathrm{~cm}$ was the same as those at 70-75 cm (Table 2). As a result, both the estimates were almost the same (1.50 vs. 1.53).

The contribution of 25\% was much lower than 60, 50-70, 92 and 40-60\%, respectively, from a degraded peatland (Wosten et al., 1997), an agricultural field (Murayama and Baker, 1996b), oil palm and acacia plantations (Hooijer et al., 2012) and a meta-analysis (Couwenberg et al., 2009). Hooijer et al. (2012) calculated PDs using the contribution of $92 \%$ to be 2129 and $1856 \mathrm{~g} \mathrm{C} \mathrm{m}^{-2} \mathrm{yr}^{-1}$, respectively, for oil palm and acacia plantations in Sumatra. On the other hand, the annual subsidence of $1.4 \mathrm{~cm} \mathrm{yr}^{-1}$ due to peat oxidation in this study was similar to those $\left(1.53 \pm 0.70 \mathrm{~cm} \mathrm{yr}^{-1}\right)$ of degraded peat swamp forests in Central Kalimantan, though annual PD was estimated to be low at $790 \mathrm{~g} \mathrm{C} \mathrm{m}^{-2} \mathrm{yr}^{-1}$ (Hooijer et al., 2014). Crucial parameters to interconvert subsidence and oxidative peat decomposition are peat properties, such as BD and carbon content (Könönen et al., 2015). Higher subsidence rates usually result from low values of BD and carbon content (Murayama and Bakar, 1996a) (Eqn. 2). In other words, low BD and carbon content result in low PD for the same subsidence. In this study, BD was over $0.20 \mathrm{~g} \mathrm{~cm}^{-3}$ at all depths (Table 2) probably because of compaction during land preparation. The BD was much higher than those of oil palm and acacia plantations in Sumatra (0.075-0.15 $\left.\mathrm{g} \mathrm{cm}^{-3}\right)$ (Hooijer et al., 2012) and undisturbed peatlands in Central Kalimantan (0.098 $\left.\mathrm{g} \mathrm{cm}^{-3}\right)$ (Shimada et al., 2001). In addition, carbon content of $42.8 \%$ in this study (Table 2) was lower than an average of 55\% (Hooijer et al, 2012; Shimada et al., 2001). The lower carbon content, especially in the surface soil $(0-5 \mathrm{~cm})$, was possibly due to the flooding of Kahayan river running about $1 \mathrm{~km}$ distant from the study site. As a result, peat carbon density, as a product of BD and carbon content, of $0.086 \mathrm{~g} \mathrm{C} \mathrm{cm}^{-3}$ in this study was higher than 0.054 (Shimada et al., 2001) and 0.041-0.083 $\mathrm{g} \mathrm{C} \mathrm{cm}^{-3}$ (Hooijer et al., 2012). The lower contribution (25\%) of PD to total subsidence was attributable to the higher carbon density due to compaction.

\section{Conclusions}

Soil $\mathrm{CO}_{2}$ efflux through oxidative peat decomposition (PD) was measured in trenching plots using the chamber method in a rubber plantation developed on tropical peat during 2015, an El Niño year. PD showed a clear seasonality and linearly increased as groundwater level (GWL) decreased. Using the strong linearity, annual PD was 
estimated from continuous GWL data to be $1406 \mathrm{~g} \mathrm{C} \mathrm{m}^{-2} \mathrm{yr}^{-1}$. However, the annual PD was determined in a strong El Niño year with drought. Thus, in a normal year without El Niño drought or in a La Niña year, annual PD in the rubber plantation most probably reduces in proportion to GWL. Similarly, the linear relationship indicates that annual PD can be simply assessed from only mean annual GWL. We also showed the seasonal variation of peat elevation in parallel with GWL. The parallel variation indicates that GWL should be considered carefully to determine peat subsidence for assessing PD using the subsidence method. Peat subsidence is sensitive to GWL independently of peat oxidation.

\section{Acknowledgements}

This study was supported by JSPS KAKENHI (no. 25257401), the Environment Research and Technology Development Fund (no. 2-1504) by the Ministry of the Environment, Japan, the Asahi Glass Foundation and Grant for Environmental Research Projects from The Sumitomo Foundation, SMARTD project by Indonesian Agency for Agricultural Research and Development, and Research project fund by Indonesian Swampland Agricultural Research Institute. We thank Dr. Hiroyuki Yamada for supporting GWL measurement.

\section{References}

Aguilos M., Takagi K., Liang N., Watanabe Y., Teramoto M., Goto S., Takahashi Y., Mukai H. and Sasa K., 2013. Sustained large stimulation of soil heterotrophic respiration rate and its temperature sensitivity by soil warming in a cooltemperate forested peatland. Tellus B. 65, 20792. doi: 10.3402/tellusb.v65i0.20792

Agus, F., Hairiah K. and Mulyani A., 2011. Measuring carbon stock in peat soils: practical guidelines. World Agroforestry Centre (ICRAF) Southeast Asia Regional Program, Indonesian Centre for Agricultural Land Resources Research and Development. Bogor, Indonesia.

Agus, F., Gunarso P., Sahardjo B. H., Harris N., Noordwijk M. V. and Killeen T. J., 2013. Historical $\mathrm{CO}_{2}$ emissions from land use and land use change from the oil palm industry in Indonesia, Malaysia and Papua New Guinea. Reports from the Technical Panels of the $2^{\text {nd }}$ Greenhouse Gas Working Group of the Roundtable on Sustainable Palm Oil (RSPO). Tropenbos International.

Ali, M., Taylor, D. and Inubushi, K., 2006. Effects of environmental variations on $\mathrm{CO}_{2}$ efflux from a tropical peatland in eastern Sumatra. Wetlands. 26, 612-618.

Carlson, K. M., Goodman, L. K. and May-Tobin, C. C., 2015. Modeling relationships between water table depth and peat soil carbon loss in Southeast Asian plantations. Environmental Research Letters. 10, 074006. doi:10.1088/17489326/10/7/074006

Comeau, LP., Hergoualc’h, K., Hartill, J., Smith, J., Verchot, L. V., Peak, D. and Salim, 
A. M., 2016. How do the heterotrophic and the total soil respiration of an oil palm plantation on peat respond to nitrogen fertiliozer application? Geoderma. 268, 41-51.

Comeau, LP., Hergoualc'h, K., Smith, J. and Verchot, L. V., 2013. Conversion of intact peat swamp forest to oil palm plantation: Effects on soil $\mathrm{CO}_{2}$ fluxes in Jambi, Sumatra. Working paper 110. CIFOR, Bogor, Indonesia.

Couwenberg, J., Dommain, R. and Joosten, H., 2009. Greenhouse gas fluxes from tropical peatlands in south-east Asia. Global Chang Biology. 16, 1715-1732. doi:10.1111/j.1365-2486.2009.02016.x

Couwenberg, J. and Hooijer, A., 2013. Towards robust subsidence-based soil carbon emission factors for peat soils in south-east asia , with special reference to oil palm plantations. Mires and Peat. 12, 1-13.

Dariah, A., Marwanto, S. and Agus, F., 2013. Root- and peat-based $\mathrm{CO}_{2}$ emissions from oil palm plantations. Mitigation and Adaptation Strategies for Global Change. 19, 831-843. doi:10.1007/s11027-013-9515-6

Dommain, R., Couwenberg, J., Glaser, P. H., Joosten, H. and Suryadiputra, I. N. N., 2014. Carbon storage and release in Indonesian peatlands since the last deglaciation. Quaternary Science Reviews. 97, 1-32. doi:10.1016/j.quascirev.2014.05.002

Epron, D., 2009. Separating autotrophic and heterotrophic coponents of soil respiration; lessons learned from trenching and related root-eclusion experiments. 157-168. In Soil Carbon Dynamics (ed. Kutsch, W. L., Bahn, M. and Heinemeyer, A., 2009, Cambridge University Press, New York, pp. 286.

Furukawa, Y., Inubushi, K., Ali, M., Itang, A. M. and Tsuruta, H., 2005. Effect of changing groundwater levels caused by land-use changes on greenhouse gas fluxes from tropical peatlands. Nutrient Cycling in Agroecosystems. 71, 81-91.

Global Business Guide Indonesia, 2015. Indonesia's downstream rubber industrywaiting for investors. http://www.gbgindonesia.com/en/agriculture/article/ (accessed on September 9, 2016)

Hamada, J., Yamanaka, M. D., Matsumoto, J., Fukao, S., Winarso, P. A. and Sribimawati, T., 2002. Spatial and temporal variations of the rainy season over Indonesia and their link to ENSO. Journal of the Meteorological Society of Japan. 80, 285-310.

Hanson, P. J., Edwards, N. T., Garten, C. T. and Andrews, J. A., 2000. Separating root and soil microbial contributions to soil respiration: A review of mehtods and observations. Biogeochemistry. 48, 115-146.

Harazono, Y., Iwata, H., Sakabe, A., Ueyama, M., Takahashi, K., Nagano, H., Nakai, T. and Kosugi, Y., 2015. Effects of water vapor dilution on trace gas flux, and practical correction methods. Journal of Agricultural Meteorology. 71, 65-76. doi:10.2480/agrmet.D-14-00003 
637

638

639

640

641

642

643

644

645

646

647

648

649

650

651

652

653

654

655

656

657

658

659

660

661

662

663

664

665

666

667

668

669

670

671

672

673

674

675

676

677

Hergoualc'h, K. and Verchot, L. V., 2011. Stocks and fluxes of carbon associated with land use change in southeast Asian tropical peatlands: a review. Global Biogeochemical Cycles. 25, GB2001. doi:10.1029/2009GB003718

Hergoualc'h, K. and Verchot, L. V., 2013. Greenhouse gas emission factors for land use and land-use change in Southeast Asian peatlands. Mitigation and Adaptation Strategies for Global Change. 19, 789-807. doi:10.1007/s11027-013-9511-x

Hirano, T., Jauhiainen, J., Inoue, T. and Takahashi, H., 2009. Controls on the carbon balance of tropical peatlands. Ecosystems. 12, 873-887. doi: 10.1007/s10021008-9209-1

Hirano, T., Kusin, K., Limin, S. and Osaki, M., 2014. Carbon dioxide emissions through oxidative peat decomposition on a burnt tropical peatland. Global Change Biology. 20, 555-565. doi:10.1111/gcb.12296

Hirano, T., Kusin, K., Limin, S. and Osaki, M., 2015. Evapotranspiration of tropical peat forests. Global Change Biology. 21, 1914-1927. doi:10.1111/gcb.12653

Hooijer, A., Page, S., Canadell, J. G., Silvius, M., Kwadijk, J., Wösten, H. and Jauhiainen, J., 2010. Current and future $\mathrm{CO}_{2}$ emissions from drained peatlands in Southeast Asia. Biogeosciences. 7, 1505-1514. doi:10.5194/bg-7-1505-2010

Hooijer, A., Page, S., Jauhiainen, J., Lee, W. A., Lu, X. X., Idris, A. and Anshari, G., 2012. Subsidence and carbon loss in drained tropical peatlands. Biogeosciences. 9, 1053-1071. doi:10.5194/bg-9-1053-2012

Hooijer, A., Page, S., Navratil, P., Vernimmen, R., Van der Vat, M., Tansey, K., Konecny, K., Siegert, F., Ballhorn, U. and Mawdsley, N., 2014. Carbon emissions from drained and degraded peatland in Indonesia and emission factors for measurement, reporting and verification (MRV) of peatland greenhouse gas emissions - a summary of KFCP research results for practitioners. IAFCP, Jakarta, Indonesia.

Husen, E., Salma S. and Agus F., 2014. Peat emission control by groundwater management and soil amendments: evidence from laboratory experiments. Mitigation and Adaptation Strategies for Global Change. 19, 821-829. doi: 10.1007/s11027-013-9526-3

Husnain, H., Wigena, I. G. P., Dariah, A., Marwanto, S., Setyanto, P. and Agus, F., 2014. $\mathrm{CO}_{2}$ emissions from tropical drained peat in Sumatra, Indonesia. Mitigation and Adaptation Strategies for Global Change. 19, 845-862. doi:10.1007/s11027-0149550-y

Huxman, T. E., Snyder, K. A., Tissue, D., Leffler, A. J., Ogle, K., Pockman, W. T., Sandquist, D. R. and Potts, D. L., 2004. Precipitation pulses and carbon fluxes in semiarid and arid ecosystems. Oecologia. 141, 254-268. doi:10.1007/s00442004-1682-4

Iiyama, I. and Osawa, K., 2010. Surface $\mathrm{O}_{2}$ in flux related to soil $\mathrm{O}_{2}$ profiles in a drained tropical peatland. Soil Science and Plant Nutrition. 56, 517-520. doi: 10.1111/j.1747-0765.2010.00488.x 
678

679

680

681

682

683

684

685

686

687

688

689

690

691

692

693

694

695

696

697

698

699

700

701

702

703

704

705

706

707

708

709

710

711

712

713

714

715

716

717

Indonesia Directorate General of Estate, 2013. Area, production and productivity estate crops in Indonesia. Ministry of Agriculture. Jakarta, Indonesia.

Inubushi, K., Furakawa, Y., Hadi, A., Purnomo, E. and Tsuruta H., 2003. Seasonal change of $\mathrm{CO}_{2}, \mathrm{CH}_{4}$ and $\mathrm{N}_{2} \mathrm{O}$ fluxes in relation to land-use change in tropical peatlands located in coastal area of South Kalimantan. Chemosphere. 52, 603608. doi: 10.1016/S0045-6535(03)00242-x

Ishikura, K., Yamada, H., Toma, Y., Takakai, F., Morishita, T., Darung, U., Limin, A., Limin, S. H. and Hatano, R., 2016. Effect of groundwater level fluctuation on soil respiration rate of tropical peatland in Central Kalimantan, Indonesia. Soil Science and Plant Nutrition. http://dx.doi.org/10.1080/00380768.2016.1244652

Itoh M., Kosugi Y., Takanashi S., Kanemitsu S., Osaka K., Hayashi Y., Tani M. and Rahim A. N., 2012. Effects of soil water status on the spatial variation of carbon dioxide, methane and nitrous oxide fluxes in tropical rain-forest soils in peninsular malaysia. Journal of Tropical Ecology. 28, 557-570. doi:10.1017/ S0266467412000569

Jauhiainen, J., Takahashi H., Heikkinen J. E. P., Martikainen P. J. and Vasanderet H., 2005. Carbon fluxes from a tropical peat swamp forest floor. Global Change Biology. 11:1788-1797. doi: 10.1111/j.1365-2486.2005.001031.x

Jauhiainen, J., Hooijer, A. and Page, S.E., 2012. Carbon dioxide emissions from an Acacia plantation on peatland in Sumatra, Indonesia. Biogeosciences. 9, 617630. doi:10.5194/bg-9-617-2012

Jauhiainen, J., Kerojoki, O., Silvennoinen, H., Limin, S. and Vasander, H., 2014. Heterotrophic respiration in drained tropical peat is greatly affected by temperature-a passive ecosystem cooling experiment. Environmental Research Letters. 9, 105013. doi:10.1088/1748-9326/9/10/105013

Könönen, M., Jauhiainen, J., Laiho, R., Kusin, K. and Vasander, H., 2015. Physical and chemical properties of tropical peat under stabilised land uses. Mires and Peat. $16,1-13$.

Kwon, M. J., Haraguchi A. and Kang H., 2013. Long-term water regime differentiates changes in decomposition and microbial properties in tropical peat soils exposed to the short-term drought. Soil Biology \& Biochemistry. 60, 33-44. doi: 10.1016/j.soilbio.2013.01.023

Lee X., Hui-Ju Wu, Sigler J., Oishi C. and Siccama T., 2004. Rapid and transient response of soil respiration to rain. Global Change Biology. 10, 1017-1026. doi: 10.1111/j.1365-2486.2004.00787.x

Maeght, JL., Gonkhamdee, S., Clément, C., Ayuttaya, S. I. N., Stokes, A. and Pierret, A., 2015. Seasonal patterns of fine root production and turnover in a mature rubber tree (Hevea brasiliensis Müll. Arg.) stand - Differentiation with soil depth and implications for soil carbon stocks. Frontiers in Plant Science. 6, 1022. doi: 10.3389/fpls.2015.01022 
Marchante, E., Kjøller, A., Struwe, S. and Freitas, H., 2008. Short- and long-term impacts of Acacia longifolia invasion on the belowground processes of a Mediterranean coastal dune ecosystem. Applied Soil Ecology. 40, 210-217. doi:10.1016/j.apsoil.2008.04.004

Marwanto, S. and Agus, F., 2014. Is $\mathrm{CO}_{2}$ flux from oil palm plantations on peatland controlled by soil moisture and/or soil and air temperatures? Mitigation and Adaptation Strategies for Global Change. 19, 809-819. doi: 10.1007/s11027013-9518-3

Matsuura, S., Mori, A., Hojito, M., Kanno, T. and Sasaki, H., 2011. Evaluation of a portable chamber system for soil $\mathrm{CO}_{2}$ efflux measurement and the potential errors caused by internal compensation and water vapor dilution. Journal of Agricutural Meteorology. $67,123-137$.

Melling, L., Hatano, R. and Goh, K. J., 2005. Soil $\mathrm{CO}_{2}$ Flux from three ecosystems in tropical peatland of Sarawak, Malaysia. Tellus. 57B, 1-11.

Melling, L. and Henson, I. E., 2011. Greenhouse gas exchange of tropical peatlands - a review. Journal of Oil Palm Research. 23, 1087-1095.

Melling, L., Yun Tan, C. S., Goh, K. J. and Hatano, R., 2013. Soil microbial and root respirations from three ecosystems in tropical peatland of sarawak, Malaysia. Journal of Oil Palm Research. 25, 44-57.

Miettinen, J., Hooijer, A., Shi, C., Tollenaar, D., Vernimmen, R., Liew, S. C., Malins, C. and Page, S. E., 2012. Extent of industrial plantations on Southeast Asian peatlands in 2010 with analysis of historical expansion and future projections. GCB Bioenergy. 4, 908-918. doi:10.1111/j.1757-1707.2012.01172.x

Murayama, S., and Bakar Z.A. 1996a. Estimation of in situ decomposition by measurement of $\mathrm{CO}_{2}$ flux. JARQ. 30, 153-158.

Murayama S., and Bakar Z.A. 1996b. Decomposition kinetics of organic matter of peat soils. JARQ. 30, 145-151.

Nagano, T., Osawa, K., Ishida, T., Sakai, K., Vijarnsorn, P. and Jongskul, A., 2013. Subsidence and soil $\mathrm{CO}_{2}$ efflux in tropical peatland in southern Thailand under various water table and management conditions. Mires and Peat. 11, 1-20.

Nakano, T., Sawamoto, T., Morishita, T., Inoue, G. and Hatano, R., 2004. A comparison of regression methods for estimating soil-atmosphere diffusion gas fluxes by a closed-chamber technique. Soil Biology \& Biochemistry. 36, 107-113.

Nurzakiah, S., Sabiham, S., Nugroho, B. and Nursyamsi, D., 2014. Estimation of the potential carbon emission from acrotelmic and catotelmic peats. Journal of Tropical Soil. 19, 91-99.

Page, S. E., Siegert, F., Rieley, J. O., Boehm H. V., Jaya A. and Limin S. H., 2002. The amount of carbon released from peat and forest fires in indonesia during 1997. Nature. 420, 61-65.

Page, S. E., Wust, R. A. J., Weiss, D., Rieley, J. O., Shotyk, W. and Limin, S. H., 2004. A record of late pleistocene and holocene carbon accumulation and climate 
change from an equatorial peat bog (Kalimantan, Indonesia): Implications for past, present and future carbon dynamics. Journal of Quaternary Science. 19, 625-635. doi:10.1002/jqs.884

Page, S. E., Rieley, J. O. and Banks, C. J., 2011a. Global and regional importance of the tropical peatland carbon pool. Global Change Biology. 17, 798-818. doi:10.1111/j.1365-2486.2010.02279.x

Page, S. E., Morrison, R., Malins, C., Hooijer, A., Rieley, J. O. and Jauhiainen, J., 2011b. Review of peat surface greenhouse gas emissions from oil palm plantations in Southeast Asia. White Paper Number 15. Indirect Effects of Biofuel Production Series. International Council on Clean Transportation Funding. Washington DC.

Pathiratna., 2006. Management of intercrops under rubber: implications of competition and possibilities for improvement. Bulletin of the Rubber Research Institute of Sri Lanka. 47, 8-16.

Ritung, S., Wahyunto and Sukarman., 2011. Peat land map of Indonesia, Scale 1:250.000. Indonesian Center for Agroclimate Research and Development, Indonesian Agency for Agricultural Research and Development, Ministry of Agriculture. Jakarta, Indonesia.

Schiermeier, Q., 2015. Hunting the Godzilla El Niño. Nature. 526, 490-491.

Schrier-Uijl, A. P., Silvius, M., Parish, F., Lim, K. H., Rosediana, S. and Anshari, G., 2013. Environmental and social impacts of oil palm cultivation on tropical peat - a scientific review. Roundtable on Sustainable Palm Oil. Kuala Lumpur, Malaysia.

Shimada, S., Takahashi, H., Haraguchi, A. and Kaneko, M., 2001. The carbon content characteristics of tropical peats in Central Kalimantan, Indonesia: Estimating their spatial variability in density. Biogeochemistry. 53, 249-267.

Subke, JA., Inglima, I., and Cotrufo, M. F., 2006. Trends and methodological impacts in soil $\mathrm{CO}_{2}$ efflux partitioning: A metaanalytical review. Global Change Biology. 12, 1-23. doi:10.1111/j.1365-2486.2006.01117.x

Sundari, S., Hirano, T., Yamada, H., Kusin, K. and Limin, S., 2012. Effects of groundwater level on soil respiration in tropical peat swamp forests. Journal of Agricultural Meteorology. 68, 121-134.

Verheye, W., 2010. Growth and production of rubber. In: Verheye, W. (ed.), Land Use, Land Cover and Soil Sciences. Encyclopedia of Life Support Systems (EOLSS). UNESCO-EOLSS Publishers. Oxford, UK.

Wahyunto, Nugroho, K., Ritung, S. and Sulaeman, Y., 2014. Indonesian peatland map: Method, certainty, and uses. Indonesian Center for Agroclimate Research and Development, Indonesian Agency for Agricultural Research and Development, Ministry of Agriculture. Jakarta, Indonesia.

Wosten, J. H. M. 1997. Peat subsidence and its practical implications : a case study in Malaysia. Geoderma. 78, 25-36. 